International Journal of Instruction

e-ISSN: 1308-1470 • www.e-iji.net

Article submission code:

20200728073248

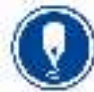

Received: 28/07/2020

Revision: 31/12/2020
July $2021 \bullet$ Vol.14, No.3

p-ISSN: 1694-609X

pp. $535-546$

Accepted: 27/01/2021

OnlineFirst: 03/06/2021

\title{
The Effectiveness of Infusion of Metacognition in van Hiele Model on Secondary School Students' Geometry Thinking Level
}

\section{Muhammad Ammar Naufal}

Ph.D., Universitas Negeri Makassar, Indonesia \& Universiti Teknologi Malaysia, Malaysia, mammarnaufal19@gmail.com

\section{Abdul Halim Abdullah}

Assoc. Prof. Dr., Universiti Teknologi Malaysia, Malaysia, p-halim@utm.my

\section{Sharifah Osman}

Dr., Universiti Teknologi Malaysia, Malaysia, sharifah.o@utm.my

\section{Mohd Salleh Abu}

Prof. Dr., Universiti Teknologi Malaysia, Malaysia, salleh@utm.my

\section{Hisyam Ihsan}

Assoc. Prof. Dr., Universitas Negeri Makassar, Indonesia, hisyamihsan@gmail.com

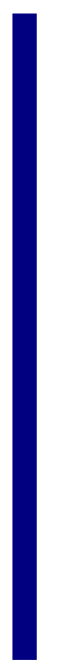

\begin{abstract}
Metacognition is the ability to think about thinking. One of the learning models in geometry is the van Hiele model, which consists of learning phases and geometry thinking level. However, geometry learning strategy in Indonesia does not stress metacognition and geometry thinking level. Hence, this study aims to examine the effectiveness of geometry learning strategy based on the infusion of metacognition in van Hiele model compared to van Hiele learning phases in helping secondary school students to improve their geometry thinking level. The quasi-experimental study was conducted six-week with 90 students. The students selected purposively divided into two groups, with 30 students in both treatment groups, respectively. The instrument employed van Hiele Geometry Test (vHGT) before and after the treatment to measure the student's geometry thinking level. Data were in ordinal form analyzed descriptively and inferentially using Mann-Whitney U. The result revealed the significant difference between the final geometry thinking level in both groups. Thus, it can be concluded that the geometry learning strategy based on the infusion of metacognition in van Hiele model is more effective in improving the student's geometry thinking level than the geometry learning strategy based on van Hiele model.
\end{abstract}

Keywords: geometry thinking level, van Hiele model, secondary school, metacognition, geometry, van Hiele learning phases

Citation: Naufal, M. A., Abdullah, A. H., Osman, S., Abu, M. S., \& Ihsan, H. (2021). The effectiveness of infusion of metacognition in van Hiele model on secondary school students' geometry thinking level. International Journal of Instruction, 14(3), 535-546. https://doi.org/10.29333/iji.2021.14331a 


\section{INTRODUCTION}

Geometry is one of the subjects in mathematics that is not easily mastered by various learners in the world. Trends in International Mathematics and Science Study (TIMSS) 2015 (Mullis et al., 2016) reported that learners across the world such as Norway, Turkey, Georgia, South Africa, and Thailand have low performance in Geometry. However, the low achievement in geometry experienced by students over the world is also experienced by Indonesian students. This phenomenon is evidenced by TIMSS 2011 (Mullis et al., 2012) showed that Indonesia was only able to rank fifth from the bottom for geometry. Moreover, Puspendik (2012) reported that the results of TIMSS involved Indonesian students from year to year decrease gradually. The test result showed Indonesia was ranked $38^{\text {th }}$ with a score of 377 from 42 countries involved. This issue was reinforced by several researchers across countries (Akgül, 2014; Atebe \& Schäfer, 2011; Jelatu et al., 2018; Md. Yunus et al., 2019; Meng \& Idris, 2012) found that students' geometry achievement in secondary school was unsatisfactory. This is because there is a correlation between low geometry achievement and low geometry thinking level of students (Crowley, 1987; Idris, 2005; Yazdani, 2007) as well as lack of metacognition (Finnell, 1992; Garofalo \& Lester, 1985; Şefik et al., 2018).

Garofalo \& Lester (1985) and Schoenfeld (1992) explain that metacognition is one of the important elements in learning mathematics and geometry in particular to control thought processes. The learners need the skill to evaluate their ability to think in performing complex tasks and think of alternative way when the act of planning seem less efficient and deadlock (Kramarski et al., 2002; Mevarech \& Kramarski, 2014). The learners who use their metacognition will be a critical thinker, able to solve problems, and make a good decision compared to those who do not use it (Flavell, 1979). Metacognition can also help learners to identify problems that need to be solved, find out what the problems are, and understand how to reach the solution of problems (Kuzle, 2013). Thus, learners can achieve a better level of geometrical achievement as expected (In'am \& Hajar, 2017; Inam, 2016). However, not many studies have focused on the implementation of metacognition in geometry learning (Kramarski et al., 2002; Mevarech \& Kramarski, 2014) particularly the infusion of metacognition in the van Hiele model (Finnell, 1992; Şefik et al., 2018).

Apart from that, geometry learning based on van Hiele model is poorly executed and inadequately improve geometry thinking level of Indonesian students (Abu \& Abidin, 2013), while this learning strategy has been used in other countries for the purpose of the improvement of geometry thinking level (Abdullah et al., 2014; Abdullah \& Zakaria, 2013a, 2013b; Abu et al., 2012; Alex \& Mammen, 2016; Atebe \& Schäfer, 2011; Connolly, 2010; Haviger \& Vojkůvková, 2015; Hock et al., 2015; Kekana, 2016; Meng \& Idris, 2012; Pujawan et al., 2020; Siew et al., 2013). Crowley (1987) explains that the van Hiele model consists of five levels of thinking. These levels of thinking labeled as L0 'visualization', L1 'analysis', L2 'informal deduction', L3 'formal deduction', and L4 'rigor'. Assisted by learning strategies, Crowley (1987) asserts that the geometry thinking level of students will progress sequentially from LO to the highest level, which 
is L4 rigor. Thus, van Hiele (1999) proposes five learning phases known as 'information', 'guided orientation', 'explication', 'free orientation', and 'integration'.

In Malaysia, for instance, despite there have been many studies on van Hiele model, however, geometry learning strategy is still performed by the teachers according to the lesson plan made and implemented in the classroom without considering geometry thinking level of students (Abdullah \& Zakaria, 2013b; Wahab et al., 2018). A similar case occurred in Indonesia that geometry learning strategy is not conducted based on the van Hiele model (Abu \& Abidin, 2013; Naufal et al., 2020). As a result, the students are unable to reach the expected geometry thinking level. Misnasanti and Mahmudi (2018) found that the majority of students $(77.67 \%$ ) are at level 0 (visualization), $19.42 \%$ are at level 1 (analysis), and $2.91 \%$ are at level 2 (informal deduction). In line with the findings by Hardianti et al. (2017) that geometry thinking level of Indonesian students is at a low level that should be improved. Nonetheless, the van Hiele model is inadequate to empower the progression of students in regulating their thinking and improving their geometry thinking level. In fact, metacognition is considered necessary applied in the learning process to improve student's geometry thinking level (Finnell, 1992; Rofii et al., 2018; Şefik et al., 2018).

Therefore, the intent of this study is to examine the effectiveness of geometry learning strategy based on the infusion of metacognition in van Hiele model compared to van Hiele learning phases in helping Indonesian secondary school students to improve their geometry thinking level.

\section{METHOD}

A total of 90 secondary school students (17-18-year-old) in the Senior High School of 5 Makassar were involved in this quasi-experimental study. They consisted of 30 students in the treatment group, who were those learning the topic of Distance in Solids by implementing the Geometry Learning Strategy based on the infusion of Metacognition by Garofalo \& Lester (1985) in van Hiele model (namely GLS-MvH) and 30 students in another treatment group, who learned the same topic by applying the Geometry Learning Strategy based on van Hiele's learning phases (namely GLS-vH). The study did not use a control group since the researcher was only interested to focus on the improvement of geometry thinking level. Accordingly, this study carried out a comparative examination between two treatment groups that utilized the GLS-MvH and the GLS-vH, respectively. The effectiveness of both treatment groups was assessed through the examination of the improvement of geometry thinking level after using these geometry learning strategies.

The study used van Hiele Geometry Test (vHGT) to evaluate the students' geometry thinking levels developed by The Cognitive Development and Achievement in Secondary School Geometry project (CDASSG) (Usiskin, 1982) and applied upon 2900 secondary school students with $r=0.64$ (Pusey, 2003). Apart from that, the Indonesian version of vHGT was obtained from Abu and Abidin (2013). The vHGT comprised 25 items and designed to investigate the students' van Hiele geometry thinking levels whether their level of thinking was at *L0, L0, L1, L2, L3, or L4. They were considered 
being mastered at that level if the students answered at least three out of five questions correctly at any level. Thus, Usiskin (1982) established marking criteria as well as weighted van Hiele geometry thinking test scores to define the van Hiele's geometry thinking levels, as depicted in Table 1 and Table 2, respectively.

Table 1

Marking criteria of the vHGT

\begin{tabular}{lll}
\hline Question Number & van Hiele's Geometry Thinking Levels & Mark \\
\hline $1-5$ & Level 0: Visualization & 1 \\
\hline $6-10$ & Level 1: Analysis & 2 \\
\hline $11-15$ & Level 2: Informal Deduction & 4 \\
\hline $16-20$ & Level 3: Formal Deduction & 8 \\
\hline $21-25$ & Level 4: Rigor & 16 \\
\hline
\end{tabular}

For instance, the students at L2 obtained the scores at L0 (questions $1-5$ ), L1 (questions $6-10$ ), and L4 (questions $21-25$ ), then their weighted sum score was 19 (1 $+2+16$ ). However, based on the tables, the students only achieve up to L2 since they fulfill the criteria in L0 and L1 sequentially and skip the L2 and L3 although they fulfill the criteria in L4.

Table 2

Weighted van Hiele geometry thinking test scores

\begin{tabular}{ll}
\hline Forced van Hiele Level & Weighted Sum Score \\
\hline L0 & $0,2,4,8,16,18,20$ or 24 \\
\hline L1 & $1,5,9,17,21$ or 25 \\
\hline L2 & $3,11,19$ or 27 \\
\hline L3 & $6,7,22$ or 23 \\
\hline L4 & $13,14,15,29,30$ or 31 \\
\hline L0 Not fit & $10,12,26$ or 28 \\
\hline
\end{tabular}

For the research procedure, permission was first obtained from the educational authorities, namely Dinas Pendidikan Kota Makassar. The permission letter produced was given to the headmaster of the school in Makassar, Indonesia. The researcher conducted the study directly to ensure that the treatments ran well and smoothly based on the geometry learning strategies developed for performing in eight meetings (four weeks). Prior to starting the research, the students in both treatment groups were tested using vHGT to investigate their initial van Hiele's geometry thinking level. Then, the treatment groups were asked to endure learning sessions with the assistance of the GLS$\mathrm{MvH}$ and the GLS-vH, respectively. In the GLS-MvH, the students were treated the learning activities based on the van Hiele learning model with additional metacognitive activities such as orientation, organization, execution, and verification (Garofalo \& Lester, 1985). The form of metacognitive activities was the metacognitive questions integrated into the van Hiele learning phases. In that way, the students engaged their thinking while working. Whereas, in the GLS-vH, the students were only given the learning activities based on the van Hiele model. Each of the sessions of learning took one and a half hours and was conducted in the normal classes (according to the mathematics teacher schedule). It operated two times a week for six consecutive weeks. 
During the session of learning, the learner implemented self-instructed learning activities prescribed in the respective GLS-MvH activities starting from activity 1 and followed by activity 2 until activity 9. It was also asked each learner from another treatment group to perform learning activities in the respective GLS-vH activities starting from activity 1 to activity 9. It must be noted that we did not teach the Distance in Solids at all. Instead, we provided the instructions to the students what to do and also to provide minimal aid to elucidate the activities of learning and some misunderstanding of the concept of the topic. This help was given only as necessary. Once the learning sessions ended, the vHGT was given to the students again to examine their final van Hiele's geometry thinking levels.

Data obtained was in ordinal form analyzed descriptively and inferentially. Descriptive analysis was used to obtain percent, mode, and median score before (pre) and after (post) the intervention. The improvement of van Hiele's geometry thinking level was then categorized as 'Between Levels' (*L0 to L0, L0 to L1, and L1 to L2) and 'Jump Phenomena' (*L0 to L1 or L2, and L0 to L2). No improvement when they categorized as 'No Improvement at all' (*L0 to ${ }^{*} \mathrm{~L} 0, \mathrm{~L} 0$ to $\mathrm{L} 0, \mathrm{~L} 1$ to $\mathrm{L} 1$, and L2 to L2) and 'Decline' (L2 to L1 or L0 or *L0, L1 to L0 or *L0, and L0 to *L0). Meanwhile, the inferential analysis used Mann-Whitney U (Gravetter \& Wallnau, 2013; Leech et al., 2015) to examine the effectiveness of both treatment groups on students' van Hiele's geometry thinking level. The effectiveness was then reinforced by referring to the Mean Rank and the value of Mann-Whitney $\mathrm{U}$ with a value of $p<0.05$.

\section{FINDINGS AND DISCUSSION}

By using the procedures described earlier, the vHGT scores assembled from both treatment groups prior to and after the intervention of GLS-MvH and of GLS-vH have been analyzed as compiled in Table 3 . The findings clearly showed that the majority of the students before the intervention of GLS-MvH as well as GLS-vH have initial geometry thinking levels of * L0 and L0 with the mode of zero and median was one and zero, respectively. It indicated that the students could be considered as unsatisfactory if they did not meet the van Hiele's geometry thinking level requirements to learn geometry effectively. During the learning of Distance in Solids, the students only achieved on the lower geometry thinking level of visualization and analysis. It could be concluded that their understanding was rather low as portrayed by the total scores of $83.3 \%(* \mathrm{LO}=43.3 \%$ and $\mathrm{LO}=40.0 \%$ for GLS-MvH) and $90.0 \%(* \mathrm{~L} 0=63.3 \%$ and $\mathrm{L} 0$ $=26.7 \%$ for GLS-vH). 
Table 3

Descriptive of van Hiele's geometry thinking level

\begin{tabular}{llllllll}
\hline \multirow{2}{*}{ Intervention } & \multirow{2}{*}{ Test } & \multicolumn{2}{l}{ Number of Students (\%) } & & Mode & Median \\
\cline { 3 - 8 } & & $*$ L0 & L0 & L1 & L2 & & \\
\hline \multirow{2}{*}{ GLS-MvH } & Pre & $13(43.3)$ & $12(40.0)$ & $4(13.3)$ & $1(3.3)$ & 0 & 1 \\
\cline { 2 - 8 } & Post & $2(6.7)$ & $12(40.0)$ & $13(43.3)$ & $3(10.0)$ & 2 & 2 \\
\hline \multirow{2}{*}{ GLS-vH } & Pre & $19(63.3)$ & $8(26.7)$ & $2(6.7)$ & $1(3.3)$ & 0 & 0 \\
\cline { 2 - 8 } & Post & $8(26.7)$ & $18(60.0)$ & $4(13.3)$ & $0(0.0)$ & 1 & 1 \\
\hline
\end{tabular}

Table 4

Number of percentages of students for each category of improvement of van Hiele's geometry thinking level after the intervention

\begin{tabular}{|c|c|c|c|c|c|c|c|c|}
\hline \multirow{3}{*}{$\begin{array}{l}\text { Geometry Learning } \\
\text { Strategy }\end{array}$} & \multicolumn{8}{|c|}{$\begin{array}{l}\text { The Category of Improvement of van Hiele's Geometry Thinking } \\
\text { Level }\end{array}$} \\
\hline & \multicolumn{2}{|c|}{$\begin{array}{l}\text { Between } \\
\text { Levels }\end{array}$} & \multicolumn{2}{|c|}{ Jump Phenomena } & \multicolumn{2}{|c|}{$\begin{array}{l}\text { No } \\
\text { Improvement } \\
\text { at all }\end{array}$} & \multicolumn{2}{|c|}{ Decline } \\
\hline & $\mathrm{N}$ & $\%$ & $\mathrm{~N}$ & $\%$ & $\mathrm{~N}$ & $\%$ & $\mathrm{~N}$ & $\%$ \\
\hline GLS-MvH & 17 & 56.7 & 5 & 16.7 & 6 & 20.0 & 2 & 6.7 \\
\hline GLS-vH & 14 & 46.7 & 1 & 3.3 & 12 & 40.0 & 3 & 10.0 \\
\hline Overall & 31 & 51.7 & 6 & 10.0 & 18 & 30.0 & 5 & 8.3 \\
\hline
\end{tabular}

Based on Table 4, it can be concluded that more than half of the students attained in developing the improvement of van Hiele's geometry thinking levels in the category of between levels $(51.7 \%)$ and of jump phenomena (10.0\%), respectively. Meanwhile, only $30.0 \%$ and $8.3 \%$ of students did not show the improvement at all even decline.

For the GLS-MvH, more than half of students successfully managed to improve their van Hiele's geometry thinking levels in the category of between levels $(56.7 \%)$ and of jump phenomena (16.7\%), whereas, for the GLS-vH, a total of $50 \%$ of the students succeeded in developing their van Hiele's geometry thinking levels in the category of between levels $(56.7 \%)$ and of jump phenomena (16.7\%). Only $20.0 \%$ and $6.7 \%$ of students in the GLS-MvH treatment group failed to show improvement at all. In the meantime, half of the students in the GLS-vH treatment group did not perform well in developing the improvement of their van Hiele's geometry thinking levels. These findings indicate that the GLS-MvH rather than the GLS-vH possessed the high potential to aid students in progressing through respective van Hiele's geometry thinking levels.

Table 5

Inferential statistics of geometry thinking level after intervention

\begin{tabular}{llll}
\hline \multirow{2}{*}{$\begin{array}{l}\text { Geometry } \\
\text { Thinking Level }\end{array}$} & Geometry Learning Strategy (GLS) & $\mathrm{N}$ & Mean Rank \\
\cline { 2 - 4 } & GLS-MvH & 30 & 37.70 \\
\cline { 2 - 4 } & GLS-vH & 30 & 23.30 \\
\cline { 2 - 4 } & Total & 60 & \\
\hline
\end{tabular}


Table 6

Mann-whitney U test between GLS-MvH and GLS-vH

\begin{tabular}{ll}
\hline & van Hiele's Geometry Thinking Levels \\
\hline Mann-Whitney U & 234.000 \\
\hline Asymp. Sig. (2-tailed) & -3.468 \\
\hline
\end{tabular}

Based on Tabel 5 and 6, it can be seen that the mean rank of GLS-MvH and GLS-vH on students' geometry thinking levels were compared. It indicates that there is a significant difference between both groups after intervention on student's geometry thinking level with the Mann-Whitney U result of 234.000 and $p=0.001<0.05$. The students in GLSvH have a low mean rank (23.30) on geometry thinking level while the students in GLS$\mathrm{MvH}$ have a high mean rank of 37.70 . It clearly means that the effectiveness of the intervention of GLS-MvH is higher than the GLS-vH.

The findings are parallel with Abdullah \& Zakaria (2013b), Abu \& Abidin (2013); Naufal et al. (2020); and Wahab et al. (2010) who found that most of the students achieved L0 visualization prior to being conducted the intervention. After the intervention, the majority of the students successfully attained L1 analysis and L2 informal deduction (Abdullah \& Zakaria, 2013a; Abu et al., 2012). This is probably because the L0 visualization is the most basic level that the student does not involve the reasoning ability to explain the properties of the Shapes in their perspective (Crowley, 1987). In addition, metacognition is the main factor that cause the GLS-MvH is more effective in improving students' geometry thinking level than the GLS-vH. This is due to the students are guided their thinking by metacognition such as orientation, organization, execution, and verification (Finnell, 1992; Garofalo \& Lester, 1985) so that they can plan, monitor, and evaluate their work.

Based on the result, the van Hiele learning phases have not increased sufficiently the student's van Hiele's geometry thinking levels. Learning geometry strategy in the classroom should be more improved in helping students to cope their difficulties in terms of van Hiele level of geometry thinking in order to obtain the expected van Hiele level of geometry thinking. According to Flavell (1979), metacognition plays an important role in developing the student's thinking. This might have an impact on the students' improvement of van Hiele's geometry thinking levels in which the metacognition intervenes the students' thinking throughout the van Hiele learning phases (Finnell, 1992; Şefik et al., 2018). In line with the study of Rofii et al. (2018) and Şefik et al. (2018), the students with a good metacognition are able to develop their level of geometry thinking because they have been able to control their thinking process so as to analyze the characteristics, traits and relationships of solid geometry and able to assess their thinking when stuck and unable to find out the solution of the geometry problem.

\section{CONCLUSION}

In conclusion, the study showed the effectiveness of GLS-MvH in improving the van Hiele's geometry thinking level of students is better than the GLS-vH in senior high 
school of 5 Makassar, Indonesia. Furthermore, the geometry thinking level is important in learning geometry involving problem solving in a three-dimensional space or distance in solids. The aspect of metacognition is also considered important for learning being applied in helping students to plan, monitor, and evaluate their thinking. Thus, the teacher should pay more serious attention to ensure that these skills can be embraced and developed by each low student level. In other words, the teaching and learning geometry based on metacognition and referring to geometry thinking level as well as van Hiele's learning phases should be integrated into geometry learning strategy in order for helping students to improve their geometry thinking level.

\section{ACKNOWLEDGEMENT}

The authors would like to thank the Ministry of Education and Universiti Teknologi Malaysia for their financial support. This work was supported by the GUP Tier 2 Grant no.Q.J130000.2653.16J12.

\section{REFERENCES}

Abdullah, A. H., Ibrahim, N. H., Surif, J., \& Zakaria, E. (2014). The Effects of Van Hiele's Phase-Based Learning on Students' Geometric Achievement and Attitude towards Geometry. 2014 International Conference on Teaching and Learning in Computing and Engineering, 317-324. https://doi.org/10.1109/LaTiCE.2014.67

Abdullah, A. H., \& Zakaria, E. (2013a). Enhancing Students' Level of Geometric Thinking Through Van Hiele's Phase-based Learning. Indian Journal of Science and Technology, 6(5), 1-15.

Abdullah, A. H., \& Zakaria, E. (2013b). The Effects of Van Hiele's Phases of Learning Geometry on Students' Degree of Acquisition of Van Hiele Levels. Procedia - Social and Behavioral Sciences, 102, 251-266. https://doi.org/10.1016/j.sbspro.2013.10.740

Abu, M. S., \& Abidin, Z. Z. (2013). Improving the Levels of Geometric Thinking of Secondary School Students Using Geometry Learning Video based on Van Hiele Theory. International Journal of Evaluation and Research in Education (IJERE), 2(1), 16-22. http://iaesjournal.com/online/index.php/IJERE

Abu, M. S., Ali, M. B., \& Hock, T. T. (2012). Assisting Primary School Children to Progress through Their van Hiele's Levels of Geometry Thinking using Google SketchUp. Procedia - Social and Behavioral Sciences, 64, 75-84. https://doi.org/10.1016/j.sbspro.2012.11.010

Akgül, M. B. (2014). The Effect of Using Dynamic Geometry Software on Eight Grade Students' Achievement in Transformation Geometry, Geometric Thinking and Attitudes Toward Mathematics and Technology. Middle East Technical University.

Alex, J. K., \& Mammen, K. J. (2016). Lessons Learnt from Employing van Hiele Theory Based Instruction in Senior Secondary School Geometry Classrooms. Eurasia Journal of Mathematics, Science and Technology Education, 12(10), 2223-2236. 
https://doi.org/10.12973/eurasia.2016.1228a

Atebe, H. U., \& Schäfer, M. (2011). The nature of geometry instruction and observed learning-outcomes opportunities in Nigerian and South African high schools. African Journal of Research in Mathematics, Science and Technology Education, 15(2), 191204. https://doi.org/10.1080/10288457.2011.10740712

Connolly, S. (2010). The Impact of van Hiele-based Geometry Instruction on Student Understanding [St. John Fisher College]. http://fisherpub.sjfc.edu/mathcs_etd_masters

Crowley, M. L. (1987). The van Hiele model of the development of geometric thought. Learning and Teaching Geometry, K-12, 1-16. http://www.csmate.colostate.edu/docs/math/mathactivities/june2007/The van Hiele Model of the Development of Geometric Thought.pdf

Finnell, L. (1992). Metacognition and the van Hiele model of thinking in geometry. In ProQuest Dissertations and Theses. Georgia State University.

Flavell, J. H. (1979). Metacognition and cognitive monitoring: A new area of cognitivedevelopmental inquiry. American Psychologist, 34(10), 906-911. https://doi.org/10.1037/0003-066x.34.10.906

Garofalo, J., \& Lester, F. K. (1985). Metacognition, Cognitive Monitoring, and Mathematical Performance. Journal for Research in Mathematics Education, 16(3), 163. https://doi.org/10.2307/748391

Gravetter, F. J., \& Wallnau, L. B. (2013). Statistics for the Behavioral Sciences (9th ed.). Wadsworth.

Hardianti, D., Priatna, N., \& Priatna, B. A. (2017). Analysis of Geometric Thinking Students' and Process-Guided Inquiry Learning Model. Journal of Physics: Conference Series, 895, 012088. https://doi.org/10.1088/1742-6596/895/1/012088

Haviger, J., \& Vojkůvková, I. (2015). The van Hiele Levels at Czech Secondary Schools. Procedia - Social and Behavioral Sciences, 171, 912-918. https://doi.org/10.1016/j.sbspro.2015.01.209

Hock, T. T., Tarmizi, R. A., Aida, A. S., \& Ayub, A. F. (2015). Understanding the primary school students' van Hiele levels of geometry thinking in learning shapes and spaces: A Q-methodology. Eurasia Journal of Mathematics, Science and Technology Education, 11(4), 793-802. https://doi.org/10.12973/eurasia.2015.1439a

Idris, N. (2005). Spatial Visualization and Geometry Achievement of Form Two Students. Jurnal Pendidikan, 1994, 29-40. http://citeseerx.ist.psu.edu/viewdoc/download?doi=10.1.1.514.1214\&rep=rep1\&type=p df

In'am, A., \& Hajar, S. (2017). Learning Geometry through Discovery Learning Using a 
Scientific Approach. International Journal of Instruction, 10(01), 55-70. https://doi.org/10.12973/iji.2017.1014a

Inam, A. (2016). Euclidean geometry problem solving based on metacognitive in aspect of awareness. Mathematics Education, 11(7), 2319-2331.

Jelatu, S., Sariyasa, S., \& Ardana, I. M. (2018). Effect of GeoGebra-Aided REACT Strategy on Understanding of Geometry Concepts. International Journal of Instruction, 11(4), 325-336. https://doi.org/10.12973/iji.2018.11421a

Kekana, G. R. (2016). Using GeoGebra in transformation geometry: an investigation based on the Van Hiele model [University of Pretoria]. https://repository.up.ac.za/bitstream/handle/2263/60947/Kekana_Using_2017.pdf?seque nce $=1$ \&isAllowed $=\mathrm{y}$

Kramarski, B., Mevarech, Z. R., \& Arami, M. (2002). The Effects of Metacognitive Instruction on Solving Mathematical Authentic Tasks. Educational Studies, 49(2), 225250. http://www.jstor.org/stable/3483076

Kuzle, A. (2013). Patterns of Metacognitive Behavior During Mathematics ProblemSolving in a Dynamic Geometry Environment. International Electronic Journal of Mathematics Education, 8(1), 20-40.

Leech, N. L., Barrett, K. C., \& Morgan, G. A. (2015). IBM SPSS for Intermediate Statistics (5th ed.). Routledge.

Md. Yunus, A. S., Mohd Ayub, A. F., \& Hock, T. T. (2019). Geometric Thinking of Malaysian Elementary School Students. International Journal of Instruction, 12(1), 1095-1112. https://doi.org/10.29333/iji.2019.12170a

Meng, C. C., \& Idris, N. (2012). Enhancing Students' Geometric Thinking and Achievement in Solid Geometry. Journal of Mathematics Education, 5(1), 15-33.

Mevarech, Z., \& Kramarski, B. (2014). Critical Maths for Innovative Societies: The Role of Metacognitive Pedagogies. OECD. https://doi.org/10.1787/9789264223561-en

Misnasanti, \& Mahmudi, A. (2018). Van Hiele Thinking Level and Geometry Visual Skill towards Field Dependent-Independent Students in Junior High School. Journal of Physics: Conference Series, 1097, 012133. https://doi.org/10.1088/1742$6596 / 1097 / 1 / 012133$

Mullis, I. V. S., Martin, M. O., Foy, P., \& Arora, A. (2012). TIMSS 2011 International Results in Mathematics. TIMSS \& PIRLS International Study Center, Lynch School of Education, Boston College Chestnut Hill, MA, USA.

Mullis, I. V. S., Martin, M. O., Foy, P., \& Hooper, M. (2016). TIMSS 2015 International Results in Mathematics. http://timssandpirls.bc.edu/timss2015/international-results/ 
Naufal, M. A., Abdullah, A. H., Osman, S., Abu, M. S., \& Ihsan, H. (2020). van Hiele Level of Geometric Thinking among Secondary School Students. International Journal of Recent Technology and Engineering (IJRTE), 8(6), 478-481. https://doi.org/10.35940/ijrte.F7541.038620

Pujawan, I. G. N., Suryawan, I. P. P., \& Prabawati, D. A. A. (2020). The Effect of Van Hiele Learning Model on Students' Spatial Abilities. International Journal of Instruction, 13(3), 461-474. https://doi.org/10.29333/iji.2020.13332a

Pusey, E. L. (2003). The van Hiele Model of Reasoning in Geometry: A Literature Review [North Carolina State University]. https://repository.lib.ncsu.edu/bitstream/handle/1840.16/2275/etd.pdf?sequence=1

Puspendik. (2012). Kemampuan Matematika Siswa SMP Indonesia Menurut Benchmark Internasional TIMSS 2011.

Rofii, A., Sunardi, S., \& Irvan, M. (2018). Characteristics of Students' Metacognition Process At Informal Deduction Thinking Level in Geometry Problems. International Journal on Emerging Mathematics Education, $2(1), \quad 89$. https://doi.org/10.12928/ijeme.v2i1.7684

Schoenfeld, A. H. (1992). Learning to Think Mathematically: Problem solving, metacognition, and sense-making in mathematics. In In D. Grouws (Ed.), Handbook for Research on Mathematics Teaching and Learning (pp. 334-370). MacMillan.

Şefik, Ö., Urhan, S., \& Sezen-Yüksel, N. (2018). Analysis of metacognitive skills and Van Hiele levels of geometric thinking through various variables. AIP Conference Proceedings, 2037, 020024. https://doi.org/10.1063/1.5078479

Siew, N. M., Chong, C. L., \& Abdullah, M. R. (2013). Facilitating Students' Geometric Thinking Through Van Hiele's Phase-Based Learning Using Tangram. Journal of Social Sciences, 9(3), 101-111. https://doi.org/10.3844/jsssp.2013.101.111

Usiskin, Z. (1982). Van Hiele Levels and Achievement in Secondary School Geometry. https://doi.org/10.1017/CBO9781107415324.004

van Hiele, P. M. (1999). Developing Geometric Thinking through Activities That Begin with Play. In Teaching Children Mathematics (pp. 310-316). NCTM.

Wahab, R. A., Abdullah, A. H., Abu, M. S., Atan, N. A., Mokhtar, M., \& Hamzah, M. H. (2018). A Learning 3D Geometry through Sketchup Make (SPPD-SUM) to Enhance Visual Spatial Skills and the Level of Geometric Thinking. Journal of Fundamental and Applied Sciences, 10(6S), 1005-1039. https://doi.org/10.4314/jfas.v10i1s.36

Wahab, R. A., Abdullah, A. H., Abu, M. S., Mokhtar, M., \& Atan, N. A. (2010). A Case Study on Visual Spatial Skills and Level of Geometric Thinking in Learning 3D Geometry among High Achievers. Man In India, 96(1-2), 489-499. 
Yazdani, M. A. (2007). Correlation between Students' level of Understanding Geometry According to the van Hieles' Model and Students' Achievement in Plane Geometry. Journal of Mathematical Sciences \& Mathematics Education, 2(2), 40-45. http://www.msme.us/2007-1-5.pdf 